\title{
UCRAINA ÎNTRE STAREA DE PACE ȘI CEA DE RĂZBOI CU RUSIA
}

\author{
UKRAINE BETWEEN PEACE AND WAR WITH RUSSIA
}

\author{
Drd. Ilie-Răsvan DUMITRU*
}

\begin{abstract}
După invadarea peninsulei Crimeea şi amplificarea conflictelor din sud-estul Ucrainei, a devenit evident că politica Rusiei este axată pe prezervarea sferei de influență și a controlului strategic asupra deciziilor și direcțiilor politice luate de statele desprinse din fostul bloc sovietic. Pentru a putea înțelege efectele războiului ruso-ucrainean asupra Occidentului, precum și pentru a putea anticipa și a contracara o posibilă evoluție viitoare a unor fenomene similare, în state cu risc geopolitic, precum Moldova, dar chiar și în state membre ale NATO, precum țările baltice, România sau Bulgaria, merită să acordăm atenție consecințelor geopolitice ale pierderii Crimeii și a provinciilor de sud-est de către Ucraina. Articolul analizează rațiunea, mecanismele și mizele care au stat la baza declanşării războiului ruso-ucrainean atât din perspectivă geopolitică, cât și istorică. Înțelegerea modului în care diferite instrumente hibride pot fi folosite de Federația Rusă pentru a influența statele din proximitatea sa și, în special, a modului în care combinarea acestora conduce la o satisfacere eficientă a scopurilor este utilă pentru a evalua și a aborda riscurile și vulnerabilitățile sistemice ale statelor aflate în zonele disputate de Rusia și de Occident, în ultimii ani.
\end{abstract}

After the Crimean Peninsula was invaded and the amplification of conflicts in South-Eastern Ukraine, it has become obvious that Russia's policy is concentrated on preserving its influence and strategic control over the decisions and political directions taken by the States from the former Soviet bloc. To understand the consequences of the Russian-Ukrainian war on the West, as well as to anticipate and counteract a possible future evolution of similar events not only in geopolitical risk states such as Moldavia, but also even in NATO members such as the Baltic countries, Romania or Bulgaria, it is worth paying attention to the geopolitical consequences of the loss of Crimea and the South-Eastern provinces by Ukraine. The article analyses the reason, mechanisms and stakes behind the Russian-Ukrainian war, from both a geopolitical and historical perspective. To understand the way in which different hybrid instruments can be used by the Russian Federation to influence the States in its proximity and, in particular, how their combination leads to effective satisfaction of the aims, it is useful to assess and address the systemic risks and vulnerabilities of States in the concerned areas of Russia and the West in recent years.

Cuvinte-cheie: Ucraina; Federația Rusă; Crimeea; războiul ruso-ucrainean; război hibrid; război limitat; maskirovka. Keywords: Ukraine; Russian Federation; Crimea; Russian-Ukrainian war; hybrid warfare; limited warfare; maskirovka.

Ucraina este un stat suveran, situat în estul Europei, al doilea ca mărime pe continent, după Rusia, ocupând o suprafață de $603,634 \mathrm{~km}^{2}$. Capitala Kiev este situată pe râul Nipru, în partea central-nordică a Ucrainei. Aceasta este mărginită de Belarus la nord, de Rusia la est, de Marea Azov și de Marea Neagră la sud, de Moldova și de România la sud-vest, și de Ungaria, de Slovacia și de Polonia la vest. Strâmtoarea Kerch, care leagă Marea Azov de Marea Neagră, separă Ucraina de Rusia, în regiunea de sud-est.

\footnotetext{
*Universitatea Națională de Apărare „Carol I" e-mail:dumitrurasvan@yahoo.com
}

Istoria Ucrainei este una complexă, originea ei plecând de la înființarea, în secolul al IX-lea, a primului stat slav estic, numit Rusia Kieveană. In secolele X și XI, acesta a devenit cel mai mare și cel mai puternic stat din Europa. Din secolul al XI-lea, slăbit de numeroasele conflicte interne și de invaziile triburilor mongole, Rusia Kievană a fost încorporată în Marele Ducat al Lituaniei, și, ulterior, în uniunea statală polono-lituaniană. La mijlocul secolului al XVII-lea, ca urmare a revoltelor interne împotriva polonezilor, a apărut un nou stat ucrainean, numit Hatmanatul Cazac, care a reușit să rămână autonom mai bine de 100 de ani. De la sfârșitul secolului al XVIII-lea, majoritatea teritoriului etnic ucrainean a fost 
înglobat în Imperiul Rus, regiunile occidentale ale acestui teritoriu (Galiția și Transcarpatia) fiind absorbite de Imperiul Austro-Ungar.

Prăbuşirea Imperiului Țarist (1917) a permis independenţa Ucrainei, din 1917 până în 1920. Din anul 1921 până în 1991, Ucraina a fost o republică a Uniunii Sovietice. Astfel, o Ucraină complet independentă a apărut abia la sfârșitul secolului al XX-lea, după lungi perioade de dominare succesivă a regatului polono-lituanian, Poloniei, Lituaniei, Cnezatului Moscovei, Rusiei și URSS. La destrămarea URSS din 1990-1991, legislativul RSS Ucrainene a declarat suveranitatea (16 iulie 1990) și apoi independența absolută (24 august 1991). Independența a fost confirmată prin aprobarea populară, într-un plebiscit, la 1 decembrie 1991, odată cu dizolvarea URSS.

Scurta retrospectivă istorică a Ucrainei scoate în evidență că teritoriul ucrainean actual a fost ocupat de diferite țări de-a lungul secolelor, frontierele fiind schimbate de mai multe ori. Unele regiuni care fac parte, în prezent, din Ucraina, au aparținut în trecut altor țări precum Austria, Polonia, Moldova sau Rusia. Teritoriul modern al Ucrainei găzduiește o varietate de grupuri etnice (ucraineni, germani, polonezi, ruși, rusini, tătari sau alte etnii) și religioase (catolici, greco-catolici, luterani, ortodocși ruși, evrei, musulmani sau alte confesiuni religioase). În perioada de apogeu a URSS, a fost dusă o politică intensivă de migrație forțată a populației, etnicii ucraineni scăzând de la 77\%, în 1959, la 73\%, în 1991. Această tendință de depopulare etnică s-a inversat după ce Ucraina și-a recâștigat independența, ajungând ca, la începutul secolului al XXI-lea, etnicii ucraineni să reprezinte mai mult de trei sferturi din populația țării. Rușii continuă să fie cea mai numeroasă minoritate, deși, în prezent, reprezintă mai puțin de o cincime din populaţie. Restul populației include: bieloruşi, moldoveni, bulgari, polonezi, maghiari, români, romi (țigani) și alte grupuri. Tătarii crimeeni, care au fost deportați cu forța în Uzbekistan și în alte republici din Asia Centrală în 1944, au început să se întoarcă în număr mare în Crimeea, după 1989; la începutul secolului XXI, ei constituiau unul dintre cele mai mari grupuri minoritare neruse.

Importanţa Ucrainei pentru Occident a crescut odată cu importanța acordată de Rusia acestui stat. Incapacitatea Occidentului de a înțelege rolul semnificativ al Ucrainei în temperarea politicii expansioniste a Rusiei a creat premisele izbucnirii conflictului ruso-ucrainean. Acest lucru nu este valabil și pentru Kremlin, în viziunea factorilor de decizie ruși, Uniunea Euroasiatică nefiind completă fără Ucraina ${ }^{1}$. Astfel, politica rusească, în special după 2000 , s-a orientat spre reconversia geopoliticii ucrainene prin reconsiderarea acesteia ca zonă tampon între Occident și Federaţia Rusă, în apartenență la spațiul euroasiatic. Faptul că anexarea Crimeii la Federația Rusă, prin ocuparea abuzivă a acesteia în 2014, a generat surpriză în cancelariile occidentale reflectă ori o slabă înțelegere din partea acestora a spiritului rus, nostalgic perioadelor de măreție istorică de sub conducerea lui Petru cel Mare, a Ecaterinei a II-a sau a lui Alexandru I, ori o subestimare inacceptabilă a capacităţii ruse de a se reinventa și de a renaște spiritul războinic al vechilor cazaci.

O zonă de interes strategic atât pentru Federația Rusă, cât și pentru Occident o reprezintă peninsula Crimeea; un fragment de pământ, cu o suprafaţă de $27.000 \mathrm{~km}^{2}$, care se extinde în Marea Neagră și care a reprezentat, de-a lungul timpului, poarta de pătrundere a grecilor, romanilor, bizantinilor, mongolilor și turcilor spre ținuturile din nordul Mării Negre, respectiv spre întinsele terenuri fertile ale câmpiei nord-europene. Situată pe țărmul nordic al Mării Negre și pe coasta vestică a Mării Azov, Crimeea este aproape o insulă, fiind legată de continent doar printr-o fâșie de pământ de aproximativ 5-7 km lățime, reprezentată de istmul Perekop. O mare parte din hotarul natural care desparte regiunea continentală a Ucrainei (Herson) de peninsula Crimeea este caracterizată printr-un ansamblu geografic, reprezentat de un sistem interconectat de lacuri și lagune aflate pe coasta de vest a Mării Azov.

În afara legăturii continentale prin istmul Perekop, Crimeea este legată de raionul Hencesk din regiunea Herson prin poduri care traversează strâmtorile Chohar și Henicesk. Accesul la extremitatea estică a peninsulei, reprezentată de regiunea Krasnodar, se face prin strâmtoarea Kerci, care conectează Marea Neagră cu Marea Azov, având o lățime de 3-13 km.

Având un mic potențial uman și economic, doar 1.967.200 de locuitori, în 2014 peninsula nu are forța politică de a juca un rol geopolitic de una singură, dar, asociată cu o mare putere, aceasta devine de o mare importanţă geostrategică, 
pentru toate regiunile din jurul său. Acest potențial geostrategic al peninsulei a fost şi motivul disputei istorice dintre marile puteri, Crimeea fiind preluată periodic, prin războaie sângeroase, de administratori diferiți (greci, romani, bizantini, mongoli, turci sau ruși). Ca și în trecut, Crimeea din prezent este o regiune sfâșiată de interesele și competiția geopolitică dintre marile puteri actuale, Uniunea Europeană, Rusia, SUA și China.

Din perspectivă geostrategică, consider că Ucraina este hinterlandul natural al peninsulei Crimeea; prin urmare, prin poziţia sa geografică, ca țară care cuprinde țărmurile nordice ale Mării Negre, Ucraina este predestinată să conducă peste această regiune. Dar o retrospectivă istorică ne arată că interesele geostrategice ale marilor puteri au determinat ca, de mai multe ori, teritorii importante strategic să fie deconectate de la legăturile lor geografice, intrând în sfera de influență a puterilor vecine (Transnistria, Osetia de Sud, Abhazia etc.) sau a imperiilor coloniale (Gibraltar, Singapore, zona Canalului Panama, Gdansk etc.).

Pentru a înțelege de ce anumite teritorii poziționate strategic au prezentat un deosebit interes pentru marile puteri, va trebui să pătrundem în esența teoriei pivoților geopolitici. Pentru unul dintre fondatorii geopoliticii ${ }^{2}$, care s-a confruntat cu problema extrem de importantă a definirii frontierelor geografice ale Ucrainei, importanța geopolitică a acesteia constă în extinderea ei în Marea Neagră, în imediata apropiere a Orientului Mijlociu. Această realitate geografică o transformă într-o veritabilă punte de legătură între Occident și Orient. Importanța acestei regiuni nu este de dată recentă, ea fiind descoperită încă din perioada elenistică, grecii fiind primii care au înființat porturile comerciale amplasate pe litoralul nordic al Mării Negre. Romanii au continuat politica de comerț a grecilor, urmați de bizantini și de republicile italiene. De altfel, imperiul comercial venețian s-a consolidat pe seama comerțului din Marea Mediterană și Marea Neagră, acesta aducând o contribuție importantă la dezvoltarea regiunilor aflate la nord de Marea Neagră. Potenţialul geostrategic al acestei regiuni a generat fricțiuni între Imperiul Otoman și cel Țarist, acestea disputându-și intens supremația asupra Crimeii. De la sfârşitul secolului al XVI-lea până în secolul al XX-lea, au fost purtate nu mai puțin de 12 războaie ruso-turce ${ }^{2}$, fiecare parte urmărind mărirea sferei de influență politică și economică asupra peninsulei.

La început de secol XX, Ucraina era văzută ca un nod de comunicație către care converg toate rutele de transport maritim dintre Asia şi Europa. Poziţionarea geografică a Ucrainei pe litoralul nordic al Mării Negre o lega de ruta de expansiune a Rusiei către Balcani și de zona de penetrare a influențelor europene către Caucaz, Iran și Turkmenistan. Astfel, crearea unei Ucraine independente proteja o serie de națiuni din Europa de Est și din zonele adiacente Asiei de expansiunea imperialistă rusă, aceasta devenind un factor de stabilitate strategică. Rudnicki concluziona că principala direcție pe care trebuia să o urmeze viitorul stat, în vederea construirii statalității ucrainene independente, trebuia să fie cea a Mării Negre, pe o axă nord-sud, care avea menirea de a uni două elemente culturale diferite: cazaci și galicieni ${ }^{4}$. Potrivit acestuia, poziţionarea pe această axă verticală a fost un răspuns constructiv ucrainean la politica rusă de tratare a spațiului ucrainean, ca o zonă tampon pentru regiunea euroasiatică și ca o zonă cu influență proprie și expansiune pentru politica germană, care viza Orientul Mijlociu. Orientarea pe acest vector a fost o strategie geopolitică ucraineană de împiedicare a divizării acesteia pe zonele de putere răsăritene și occidentale.

Poziția şcolii geopolitice anglo-saxone, prin reprezentantul și fondatorul acesteia ${ }^{5}$, a susținut teoria Heartlandului, prin care regiunea geografică din care face parte și statulucrainean este considerată unul dintre cele mai importante teritorii din lume. In viziunea acestuia, importanța geostrategică a lumii este dată de interiorul Eurasiei, considerată pivotul Heartlandului, din care face parte și Ucraina. Mackinder susținea că Asia interioară și estul Europei (inima) deveniseră centrul strategic al „Insulei Lumii”, ca urmare a declinului relativ al puterii maritime împotriva puterii terestre și a dezvoltării economice și industriale din sudul Siberiei ${ }^{6}$. Mackinder nu a dat o definiție precisă teritoriului ucrainean, însă a identificat această regiune din estul Europei ca pe un teren fertil pentru extinderea puterilor mondiale, asupra cărora anglo-saxonii ar fi trebuit să se gândească, pentru a putea prezerva un echilibru între puterile care luptă pentru controlul Heartland.

În anii 1900, când a fost emisă teoria Heartlandului, populația „Insulei Lumii” reprezenta 
aproape $90 \%$ din populația planetei ${ }^{7}$. „Insula Lumii" acoperea un mare teritoriu compus din: Europa, Asia și Africa, acestea având, de asemenea, proporții similare în economia mondială. Aceasta cuprindea imperii demografice, comerciale și coloniale, precum: Anglia, Franța, Rusia, AustroUngaria, Japonia, China, Spania, Portugalia, Germania, Imperiul Otoman sau Italia. Conform teoriei postulate de Mackinder: „Cine stăpânește Europa de Est comandă Heartland; Cine stăpânește Heartland comandă Insula Lumii; Cine stăpânește Insula Lumii comandă lumea"8. Pe baza acestor observații, Mackinder a concluzionat că majoritatea populaţiei lumii locuia în regiunea terestră eurasiatică și africană, și controlul asupra acestei „,insule mondiale” ar duce la o eventuală dominație mondială. Această insulă putea fi controlată cel mai bine din zona de pivot (inima), ceea ce ar garanta autosuficiența alimentară pentru țara care domină regiunea, iar protejarea permeabilității zonei de pivot pe mare, prin controlul accesului la Marea Neagră, ar oferi o formabilă barieră defensivă $\breve{g}^{\text {. }}$ Zona de pivot era vulnerabilă atacurilor terestre numai prin câmpiile din estul Europei, ceea ce atrage atenția asupra faptului că această regiune includea și o parte din Ucraina, în special peninsula Crimeea.

Un alt continuator al școlii geopolitice anglo-saxone este Z. Brzeziński, unul dintre cei mai importanţi teoreticieni ai globalismului contemporan. Creator al teoriei pivoților geopolitici, acesta acordă o atenție deosebită Ucrainei, reconsiderând importanța acestui stat prin locația sa geografică și efectele instabilității politice potențiale asupra comportamentului geostrategic. Ca pivot geopolitic, Ucraina poate permite accesul la zone strategice sau poate constitui un scut defensiv pentru un actor important sau chiar pentru o regiune. Din acest motiv, un aspect cheie al geostrategiei globale a Americii, ale cărei interese sunt reprezentate de Z. Brzeziński, este identificarea și protecția statelor (inclusiv a Ucrainei) care joacă rolul pivoților geopolitici. „Ucraina, un nou domeniu important pe tabloul de şah eurasiatic, este un pivot geopolitic, deoarece însăși existența unui stat ucrainean independent ajută la transformarea Rusiei. Fără Ucraina, Rusia încetează să mai fie un imperiu eurasiatic: s-ar putea să încerce totuși să obțină statutul imperial, dar ar fi apoi un imperiu preponderent asiatic, în mod constant atras în conflicte de ruinare cu națiunile recent suverane din Asia Centrală, care nu ar ajunge la un acord cu pierderea independenței și care ar fi susținută de colegii țărilor islamice din sud [...]. Dacă totuși Moscova recâștigă puterea asupra Ucrainei, împreună cu cincizeci și două de milioane de cetățeni, resurse naturale enorme și acces la Marea Neagră, va recâștiga automat posibilitatea de a deveni un imperiu puternic care leagă Europa de Asia"8.

În anii 1920, geograful german Karl Haushofer a folosit teoria geopolitică, propusă de politologul suedez Rudolf Kjellen în 1905, pentru a sprijini invazia Germaniei asupra statelor învecinate, pe care o privea ca „expansiune”. K. Haushofer este creatorul termenului "Lebensraum", adică sfera germană de influență și modul de organizare a estului slav, care urma să fie pe orbita sferei de influență exclusivă a Germaniei naziste. Teoria geopolitică a fost folosită pentru a justifica încercările unui actor statal de a se extinde pe baza propriilor sale nevoi. Haushofer a susținut că țările dens populate, precum Germania, ar trebui să fie admise și să aibă dreptul de a se extinde și de a dobândi teritoriul țărilor mai puțin populate.

Schița spațiului etnografic și teritorial al Ucrainei poate fi găsită în cartea lui Fryderyk Neumann Mittleuropa, editată în anul $1915^{11}$. Analiza efectuată de Neumann argumentează sfera de influență germană exercitată în Europa de Est, bazată pe principiul aşa-numitelor teorii ale ,productivismului”. În viziunea școlii geopolitice germane, Ucraina urma să fie alipită ,zonei productiviste germane”, să devină o zonă tampon a civilizației occidentale, un spațiu pentru expansiunea germană în Orientul Mijlociu și depozitele de hidrocarburi ale Caucazului, baza agricolă și de resurse a Germaniei, o regiune agricolă și industrială (aşa-numita „economie auxiliară”), precum și un rezervor de forță de muncă ieftină, dar calificată.

Un contestatar fervent al teoriei lui Z. Brzeziński și, în special, al întregii școli geopolitice anglosaxone de astăzi este Alexander Heli Dughin ${ }^{12}$, care are și calitatea de consilier personal al lui Putin. În viziunea acestuia, Ucraina este un stat esențial în perspectiva înființării, consolidării, impunerii și expansiunii Uniunii Euroasiatice. Dughin a subliniat în repetate rânduri ${ }^{13}$ că Ucraina intră în faza finală a existenței sale politice independente. 
Din punct de vedere geopolitic, acesta consideră că stabilitatea și unitatea Ucrainei au fost fragile chiar de la începutul existenței sale, aceasta intrând, în prezent, în faza finală a existenței sale politice independente. Dughin consideră că, în fapt, Ucraina unește două națiuni cu politici diametral opuse. O națiune creștină - „răsăriteană” -, care are un destin comun cu Marea Rusie ortodoxă. A doua națiune - "zapadniacki" - care trăiește întrun trecut legat de statul polonez şi de monarhia austro-ungară, cu o orientare culturală și politică prooccidentală. Acesta avertizează că, dacă cele două națiuni reușesc să ajungă la o înțelegere între ele, să stabilească un consens de echilibru între Europa și Rusia și să nu adere la NATO și UE, Ucraina își va putea menține independența și va supraviețui ca un singur organism politic. Dughin este adeptul proiectului Marea Europă de Est, prin reconsiderarea și reorganizarea Heartlandului, fiind de părere că, fără Ucraina, Rusia apare ca insuficientă atât sub aspect spațial-strategic, cât și sub aspect demografic sau politic ${ }^{14}$. Practic, toate analizele geopolitice scot în evidență faptul că Ucraina este legată ombilical de Rusia, aceasta din urmă fiind vulnerabilă, incompletă și știrbită de potenţialul geostrategic al teritoriului ucrainean, cu o Ucraină cuprinsă în structurile occidentale. O Ucraină occidentală care poate găzdui și o bază navală NATO este inacceptabilă pentru politica rusă, fiind percepută ca o amenințare directă la adresa siguranței, stabilităţii și integrității statului şi a întregii tradiții ruse.

În acest context geopolitic, Rusia apare ca un lider incontestabil al structurilor de integrare eurasiatică, ce reprezintă versiuni materializate ale ideologiei Dughin. Comunitatea Eurasiatică şi acum și Uniunea Economică Eurasiatică sunt mijloacele de consolidare a conducerii regionale și a renașterii imperiale ruse, considerate drept pârghii de contrabalansare a influenței occidentale, sarcina principală a conducerii ruse fiind aceea de a asigura apartenenţa Ucrainei la astfel de organizații.

Din cauza circumstanţelor internaţionale, generate de competiția economică din ce în ce mai acută, Ucraina s-a aflat în epicentrul turbulențelor geopolitice, născute din siajul competiției dintre marile puteri. Altfel spus, aceasta se află în epicentrul unui ciclon competiţional, gravitație geopolitică și ruptură civilizațională, determinată de poziția acesteia la răscrucea dintre Occident şi Orient, fapt ce îi imprimă un statut de victimă a geografiei. Astăzi, vedem o concurență sporită pentru influență în Eurasia prin coliziunea a două paradigme de integrare - europeană (economie de piaţă, democrație, civilizație occidentală) și eurasiatică (autoritarism oligarhic, corupţie şi putere administrativă autocratică).

Având în vedere politica Moscovei, de refacere a Marii Rusii, și faptul că aceasta vede expansiunea NATO spre Est ca o amenințare reală la adresa securității statului și identității ruse, toate statele cu frontieră comună cu Rusia care afișează o sensibilitate prooccidentală sunt condamnate să fie reconsiderate și să devină zone tampon pentru aceasta. În acest sens, în ultimii ani, Rusia a dus o propagandă susținută pentru determinarea factorilor politici ai Ucrainei să renunțe la proiectul Euro și să opteze, în final, în favoarea eurasianismului rus. Un astfel de pesimism politic a fost întărit în 2013 de refuzul președintelui de atunci Viktor Ianukovici de a semna Acordul de asociere Ucraina - Uniunea Europeană, în mare parte datorită promisiunilor de susținere economică din partea Federației Ruse.

După retragerea lui V. Ianukovici din funcția de președinte al Ucrainei, ca urmare a protestelor Euromaidan, din iarna anului 2013, Rusia și-a pierdut principalele mijloace de menținere a Ucrainei în sfera sa de influență geopolitică ${ }^{15}$. După fuga acestuia în Rusia și ca urmare a evenimentelor din Ucraina, succedate după preluarea puterii de către o elită politică prooccidentală, Kremlinul a început să pună în aplicare scenariul de anexare a Crimeii și a regiunii de sud-est a Ucrainei. În acest sens, Rusia a sprijinit separatiștii din aceste regiuni, ceea ce a dus la o escaladare a conflictului pe o scară mai largă. Ucraina a devenit astfel o victimă sigură a geopoliticii marilor puteri, din cauza intereselor și confruntărilor politice dintre Rusia, UE și SUA. Ca urmare a conflictelor declanșate pe teritoriul său, consider că Ucraina este victima atât a luptei sistemului rus pentru supraviețuire, cât și a incapacității Occidentului de a proteja spațiul juridic internaţional.

Schimbarea frontierelor de stat ucrainene prin anexarea peninsulei Crimeea, precum și alimentarea acestui conflict prin întreținerea tensiunilor din regiunile sud-estice ale Ucrainei, care găzduiesc o importantă comunitate rusă și prorusă, au fost o provocare prin care Rusia a zguduit lumea occidentală și ordinea mondială existentă, în 
general. Conflictul din Ucraina a deschis o nouă pagină a politicii externe rusești, a relațiilor sale internaționale și a formării strategiei de securitate. Reacția Rusiei a fost forțată de transformarea regimului politic din Ucraina, aceasta fiind luată drept o provocare pentru statutul său și o ameninţare geopolitică din partea Statelor Unite.

Potrivit majorității analiștilor militari occidentali și locali, Rusia, profitând de incertitudinea și de lipsa de reacție occidentală, încearcă ori să ,înghețe" conflictul, forțând apariția unor regiuni separatiste identice celor din Georgia sau din Republica Moldova, ori să-1 încheie în condiții favorabile, care să garanteze conservarea identităţii culturale rusești în sud-estul Ucrainei prin recunoașterea oficială a limbii ruse ca a doua limbă oficială a statului. Aceste aspecte vor garanta că Kievul nu va mai adera la NATO și UE în viitor, slăbind încorsetarea occidentală pe care o resimte acut Kremlinul.

Înciuda faptuluicăUcraina sepretindeafiopunte geopolitică între Europa și Eurasia, ea îndeplinește, în primul rând, rolul unei frontiere strategice între UE și Rusia. Vorbind despre geostrategia Rusiei, consider că Ucraina este ultimul bastion în calea democrațiilor occidentale, pentru Kremlin și pentru Rusia însăși. Prin susținerea conflictului ucrainean, Rusia încearcă să stopeze expansiunea spre est a UE şi NATO, în vederea menţinerii sferei de influență din Eurasia. Pentru Kremlin, Ucraina nu reprezintă decât o piesă pe marea tablă de șah geopolitică, în confruntarea cu SUA, alături de alte piese de joc, precum Siria, Iran sau Venezuela, victoria acesteia în războiul ucrainean fiind percepută ca o altă înfrângere a SUA.

Acțiunile ostile ale Rusiei în Ucraina au intensificat interesul strategilor militari pentru conceptul de război hibrid. Pentru mulți analiști occidentali, conceptul „hibrid” reprezintă cel mai facil mod de a descrie complexitatea și combinația de instrumente și metode folosite de Federaţia Rusă în timpul anexării Crimeii, precum și sprijinirea grupurilor separatiste din estul Ucrainei. Argumentat sau nu, în planul şi cu mijloacele vreunei credinţe, ideologii sau strategii geopolitice, războiul hibrid ruso-ucrainean reprezintă calea naturală de impunere a unor raporturi de forţe, prin determinarea Kievului de a accepta condiţiile şi viziunea Kremlinului în materie de sistem, menit să garanteze avantajele şi dominaţia Rusiei.
Ceea ce iese în evidență în conflictul din Ucraina, raportat la războiul hibrid, este accentul pus pe metodele nonmilitare și, în special, pe războiul informațional, esențial pentru campania de succes a Rusiei din Crimeea, în 2014. Strategia rusă a inclus și include o combinaţie tradiţională de tehnici de luptă convenționale (acțiuni militare clasice) și neconvenționale (operațiuni sub acoperire), dar și sprijinirea protestelor politice, constrângerile economice, operațiunile cibernetice, toate completate și susținute de o campanie intensă și agresivă de dezinformare. La nivel tactic, războiul electronic (EW), cel psihologic și sabotajele cibernetice, regăsite și în conflictul ruso-georgian din 2008, au diminuat capacitatea autorităţilor ucrainene de răspuns, în timp ce tehnicile mai largi de manipulare și exploatare media au diluat frontierele dintre adevăr și minciună, creând realităţi alternative pentru observatorii care au agreat poziția presei ruse în privința evenimentelor.

Rusia a folosit intense operațiuni de informare și propagandă pentru a influenţa și a modela percepția publică, exploatând vulnerabilităţile societale existente, subminând legitimitatea percepută a statului ucrainean și slăbind instituțiile guvernamentale și de stat. În Ucraina, propaganda rusă s-a adaptat pentru a exploata sentimentele conservatoare, ortodoxe și naționaliste, menite să sporească opoziţia față de integrarea cu restul Europei, prin specularea nivelului ridicat de conservatorism cultural, puternica opoziţie față de categoriile LGBT, precum și integrarea minorităților religioase. Războiul informațional declanșat de Kremlin în războiul ucrainean excede banala propagandă care promovează diverse realităţi veridice, urmărind, printr-o propagandă agresivă și insidioasă, crearea unor realități paralele care alterează sau influențează deciziile de politică externă, securitate și apărare ale Ucrainei ${ }^{16}$. Realitățile alternative, promovate în acest conflict printr-o propagandă subversivă care pervertește adevărul obiectiv, a urmărit și urmărește denaturarea percepției unui public țintă.

Manipularea mentalului colectiv rus, ucrainean sau occidental prorus se realizează în spectrul vizibil, concertat, planificat, integrat și etapizat, prin atingerea următoarelor obiective:

- promovarea directă a Rusiei, a liderilor și a narațiunilor sale oficiale, care sunt prezentate într-o lumină naționalistă, patriotică, conservatoare, 
istorică grandioasă, loială spiritului rus și valorilor creștine ortodoxe;

- sădirea incertitudinii, amplificarea dilemelor, inocularea subtilă a unor false adevăruri. Aceasta se realizează printr-o propagandă subtilă care generează emoții prin activarea unor centre de sensibilitate personală. Obiectivul are rolul de a forma din rândul populației o masă de manevră care are o slăbiciune și apetență pentru teoriile conspiraționiste, care practică suspiciunea ca regulă și care prezintă un puternic caracter critic la orice element de decizie sau de construcție internă;

- identificarea dușmanului comun, prin al cărui construct se imprimă coeziunea și menținerea unității societăţii ruse în jurul liderilor;

- construirea unei stări de spirit bazat pe frici, temeri și incertitudini. Acest obiectiv urmărește pregătirea stărilor de spirit, condiționarea reacțiilor și activarea la un moment dat a anumitor reflexe anterior condiționate;

- construirea unui instrumentar uman care să poată fi activat la momentul oportun. În această etapă, sunt identificați, racolați și pregătiți pentru activare perdanții, suporterii, nemulțumiții, idioții utili, grupurile de sprijin și masele de manevră. Partea cea mai importantă a acestei componente este identificarea, selectarea, instruirea și condiționarea persoanelor convinse de narațiunile alternative, prin rescrierea percepțiilor din mentalul individual. Aceste persoane sunt pregătite să devină manipulatori conștienți, dezinformatori obedienți, consimţitori ai războiului informațional.

Planificarea războiului informațional $\mathrm{s}-\mathrm{a}$ realizat pe trei paliere: global, regional și local. Astfel, pe fondul deteriorării vieții și a situaţiei economice interne din Rusia, autoritățile ruse s-au repliat, fiind capabile să distragă atât populaţia occidentală, cât și cea ucraineană sau cea rusă de la problemele sociale, mizând pe exploatarea tezei nostalgice a caracteristicilor speciale ale Rusiei. În acest sens, centrul spiritual al Bisericii Ortodoxe este promovat ca o ultimă redută de protecție ortodoxă împotriva unui mediu ostil, reprezentat de Vestul depravat ${ }^{17}$. În plus, este distrasă atenția de la toate fricțiunile și tensiunile interne din Rusia, prin promovarea mass-mediei aservite și a propagandei, care încearcă să arate că politica SUA se îndreaptă în direcția izolării și distrugerii suveranității ruse. Astfel, una dintre componentele principale ale politicii ruse este crearea unui inamic care să ajute la consolidarea încrederii și coeziunea societății din jurul regimului și liderului.

$\mathrm{Cu}$ toate acestea, sprijinul popular și politic pentru escaladarea conflictului din Ucraina ar trebui privit ca o încercare a elitei ruse de a menține sistemul autoritar al lui Putin, în condițiile recesiunii și sancțiunilor impuse. Europenizarea cu succes și prosperitatea Ucrainei ar pune sub semnul întrebării eficacitatea regimurilor antidemocratice, extrapolând efectul asupra multor țări ex-sovietice, inclusivîn Rusia. Fiascoul strategiei de transformare cu succes în Ucraina ar servi drept un exemplu clar de revoltă democratică a unei mari țări ortodoxe, pentru societatea rusă. Prin urmare, intervenția militară limitată a Rusiei în Ucraina vizează, în primul rând, prevenirea reformelor prooccidentale de la Kiev. De asemenea, putem presupune că strategia Rusiei are ca scop epuizarea economică, retragerea sprijinului popular și prăbușirea administrativă a Ucrainei, nu prin intervenția militară deschisă la scară largă și subversiunea provocării statului, ci prin amplificarea nemulţumirii populaţiei şi îndepărtarea autorităților prooccidentale.

Utilizarea trupelor speciale a fost evidentă în conflictul din 2014, deși angajarea acestora nu este o strategie nouă în gândirea militară rusă. Cunoscute sub numele de unități Spetsnaz, aceste forțe au fost concepute cândva, în a doua jumătate a secolului XX, pentru a desfășura misiuni de „recunoaștere specială” (dobândirea de informații despre instalațiile economice și militare majore și fie distrugerea lor, fie scoaterea lor din acțiune; efectuarea de operațiuni punitive împotriva rebelilor, desfășurarea propagandei; formarea și instruirea detaşamentelor insurgenților etc.), pentru a submina potențialul politic, economic și militar și moralul unui dușman probabil sau real. În Crimeea, omuleții verzi au fost desfășurați pentru preluarea controlului instituțiilor publice, guvernamentale, precum și a obiectivelor cheie ale infrastructurii critice. Pentru legitimizarea acțiunii ruse, forțele Spetsnaz au facilitat și au susținut înarmarea miliției separatiste. După surpriza provocată Occidentului de șocul invaziei Crimeii, agresiunea hibridă rusă împotriva Ucrainei s-a transformat încet, dar sigur, într-o fază de antrenament intrabelic. Astfel, conflictul ruso-ucrainean a devenit un război intern, bazat pe conflictul civil, declanșat și alimentat din exterior, în care un agresor participă insidios și ascuns prin trupe subversive și miliții 
locale, precum și prin „formațiuni de voluntari”, grupuri de străini şi mercenari. În tot acest timp, prin promovarea unei intense propagande negre, guvernul rus a provocat incertitudine și confuzie, negând în mod repetat implicarea Rusiei în acest conflict.

Alte instrumente și tehnici de război hibrid au fost folosite pentru a demoraliza, a demotiva și a intimida trupele ucrainene. Acestea au inclus exerciţii militare de amploare, desfăşurate cu trupe convenționale la granița ucraineană, atacuri cibernetice asupra sistemelor guvernamentale ucrainene, război electronic care a bruiat posturile media ale Ucrainei, o ofensivă diplomatică și mass-media intensă pentru subminarea legitimității noului guvern ucrainean. Scopul final al acestui tip de ,război” este de a aplica o presiune psihologică pentru a provoca prăbușirea statului țintă din interior, astfel încât obiectivele politice ale conflictului să poată fi atinse fără luptă - identic domeniului abilităților strategice, regăsite în Arta Războiului a lui Sun Tzu.

Multe dintre metodele și instrumentele folosite de Rusia în conflictul ucrainean datează din epoca sovietică, prin aplicarea maskirovka ${ }^{18}$ (deghizare, camuflaj, diversiune sau înșelăciune militară). Maskirovka se folosește de metode de camuflare a acțiunilor/intențiilor, de negare a acțiunilor/ intențiilor, de manipulare și dezinformare, care sunt executate atât pe timp de război, cât și pe timp de pace. În secolul al XXI-lea, progresele TIC au mărit eficiența și domeniul de aplicare maskirovka, permițând guvernului rus să folosească propagandă multimedia și dezinformare la scară statală ${ }^{19}$. Aceste metode au fost folosite pentru a sprijini politica externă a guvernului în Rusia și pentru a duce un „război informațional” mai eficient împotriva Ucrainei şi Occidentului. Eficiența războiului informațional promovat de Kremlin este dată de cultura post-adevăr din secolul XXI, care îi influențează direct pe cei care cad victime adepţilor dezinformării. Astfel, spațiul virtual devine un adevărat front de luptă care urmărește inocularea, în mentalul victimelor, a unor realități alternative. Maskirovka rusă profită de un ecosistem în continuă expansiune, în care oamenii confundă știrile false cu cele adevărate, cu atât mai mult cu cât ele sunt promovate și amplificate prin rețelele de socializare și Internet. Efectul de cascadă prin care dezinformatul devine dezinformator este exact ceea ce urmăresc trolii ruși pentru pervertirea adevărului și promovarea unor realităţi alternative.

Unul dintre mijloacele preferate de Rusia, extrase din trusa de instrumente hibride utilizate în războiul din Ucraina, este pârghia energetică. În general, experții și analiștii occidentali sunt de acord cu faptul că războiul energetic este un fenomen al spațiului post-sovietic, Rusia folosind cu predilecție politica energetică, pentru a menține fostele țări din Uniunea Sovietică în sfera sa de influență. De altfel, având în vedere apetența Kremlinului pentru acest instrument exotic, ar fi eronat să considerăm că această strategie nu poate fi aplicată și altor țări membre ale UE sau NATO. În acest sens, bazat pe experiența ucraineană, consider că unul dintre instrumentele hibride utilizate de Kremlin pentru forțarea regimului din Ucraina este componenta energetică. De altfel, în ultimii ani, Rusia a folosit intens resursa de gaze naturale ca armă energetică împotriva membrilor UE. Drept exemplu, putem aminti reducerea aprovizionării cu petrol a Republicii Cehe în anul 2008, pentru a sancționa Praga, deoarece a semnat un acord privind desfășurarea radarului american de apărare antirachetă pe teritoriul său; în 2007 Rusia a sancționat Estonia prin suspendarea livrărilor de petrol și cărbune către aceasta, pentru o lună, motivând acest fapt ca fiind o problemă de logistică; în 2015 Rusia a redus tranzitul petrolier prin porturile lituaniene cu $20 \%$, fără a explica motivul. Profitând de resursele imense de hidrocarburi, Rusia se folosește de aceasta, ca instrument energetic, pentru atingerea obiectivelor geopolitice. În războiul ruso-ucrainean, atenția deosebită acordată de Rusia infrastructurii critice energetice a Ucrainei se datorează faptului că un eventual sabotaj al acesteia nu provoacă pierderi economice semnificative doar Ucrainei, ci amenință inclusiv securitatea energetică a țărilor europene. Astfel, războiul hibrid desfășurat în Ucraina capătă valențe globale. Profitând de dependența totală de energia rusă a statului ucrainean, în toate sectoarele energetice, după anexarea Crimeii şi escaladarea luptelor din sud-estul Ucrainei, Kremlinul a lansat atacurile energetice împotriva acesteia, uzând de factorul energetic într-un format tridimensional: politic, economic și informațional. 


\section{Dimensiunea politică}

Rusia folosește politica energetică, ca instrument, pentru a-și atinge obiectivele de politică externă. Din 2015, guvernul rus a susținut insistent că, în urma încetării contractului de tranzit ruso-ucrainean, ruta de tranzit a gazelor rusești către Europa, prin teritoriul Ucrainei, va fi închisă, începând cu anul $2019^{20}$. Concomitent cu acest mesaj, Rusia a anunțat promovarea mai multor proiecte posibile pentru livrarea de gaze rusești către Europa, ocolind ruta ucraineană (Nord Stream 2, South Stream, Turkish Stream).

\section{Dimensiunea economică}

În aprilie 2014, Rusia a stabilit unilateral, pentru gazul furnizat în Ucraina, un preț de 485 de dolari pe mia de metri cubi, în timp ce țările europene au cumpărat gazul în medie cu 360 de dolari pe mia de metri cubi ${ }^{21}$. Incepând cu luna iunie a aceluiași an, Rusia a oprit livrările de gaze către Ucraina ${ }^{22}$. Concomitent cu sistarea livrărilor de gaze naturale, aproximativ $80 \%$ din minele de cărbune, din bazinele miniere Donbas și Donețk, aflate în zona controlată de fortele separatiste ruse, au fost scoase din funcțiune, în timp ce căile ferate și podurile au fost distruse. Imposibilitatea aprovizionării cu cărbune din regiunile ocupate din Ucraina a condus la o criză energetică în ajunul sezonului de încălzire 2014/2015 ${ }^{23}$. Pentru a evita lipsa de energie și situațiile de urgență, au fost implementate întreruperi ale alimentării cu energie electrică pentru populația din Ucraina, și unele întreprinderi consumatoare de energie au început să lucreze în regim de noapte, guvernul ucrainean căutând furnizorii de cărbune în întreaga lume. Lipsa de cărbune a devenit o provocare pe termen lung pentru securitatea energetică a Ucrainei, fiind afectată funcționarea întregului Sistem Energetic al Ucrainei. După anexarea Crimeii, Moscova a câștigat controlul asupra instalațiilor petroliere ucrainene situate în regiunea administrativă a Crimeii. Potrivit declarațiilor Ministerului energiei și industriei cărbunelui din Ucraina, după anexarea peninsulei, costurile instalațiilor energetice din Crimeea, inclusiv rezervele offshore, au fost estimate la 300 de miliarde de dolari ${ }^{24}$. Ca urmare a acestei agresiuni, Ucraina a pierdut nu numai instalațiile energetice de pe teritoriul Crimeii, ci și controlul asupra câmpurilor petrolifere ale raftului continental al Mării Negre. Din aceste zăcăminte de gaze naturale, un volum de două miliarde de metri cubi a fost însușit anual de Rusia.

\section{Dimensiunea informațională}

Energia a devenit un instrument de propagandă rusă prin care creează presiune psihologică informațională asupra societății ucrainene și comunității globale, în general. La începutul declanșării conflictului din Crimeea, Moscova a acuzat Kievul, fără temei și în mod repetat, de extracția neautorizată a gazelor de tranzit destinate consumatorilor europeni. Scopul acuzatiiilor false a fost să denigreze Ucraina în fața partenerilor occidentali, Ucraina fiind zugrăvită ca un furnizor nedemn de încredere în ochii acestora, și, respectiv, să cultive neîncrederea în autorităţile ucrainene. Transformările de pe piața energiei și reformarea politicii energetice naționale a Ucrainei au fost, adesea, folosite de organizațiile proruse, ca ocazie de informare, pentru evaluarea critică a acțiunii guvernamentale și accelerarea psihozei sociale ${ }^{25}$.

Concomitent $\mathrm{cu}$ instrumentarul hibrid desfăşurat de Rusia în războiul ucrainean, evoluțiile conflictului au reanimat problema războiului limitat. Conceptul de război limitat are o istorie chiar mai lungă decât cea a gestionării crizelor, dar a devenit vizibil, cu precădere, odată cu apariția armelor nucleare, care au introdus, în ecuație, miza nulă a unui conflict armat. Conceptul se bazează pe considerentul că beligeranții pot opta să nu lupte la capacitate maximă, pentru ca un conflict nici să nu câștige în intensitate, și nici să nu se extindă în spațiu și timp. Acest lucru este diferit de acceptarea acelor limite naturale impuse de resurse și de geografie și, de asemenea, de circumstanțele în care un stat puternic folosește doar forțe limitate pentru a face față oponenților cu capacităţi inferioare. Impotriva adversarilor inferiori, se pot obține victorii complete cu efort limitat. Pentru a fi un ,război limitat”, limitele trebuie acceptate de ambele părți. Este exact situația din războiul ucrainean, unde confruntarea s-a transformat într-un război interstat cu mize mari, în care una dintre părțile beligerante este o mare putere nucleară, iar cealaltă parte beligerantă se află sub aripa protectoare, de tip softpower, a unei alianțe militare care deține un impresionant arsenal nuclear. Marile armate ale părților beligerante, ținând cont de riscul escaladării conflictului militar, nu s-au deplasat una împotriva celeilalte, 
capacitățile acestora fiind ținute în rezervă, iar comunicările diplomatice fiind continuate pe tot parcursul derulării conflictului. Este cert că NATO nu a dorit și nici nu avea pârghiile necesare pentru a se implica direct în lupte, dar a trebuit să ia în considerare dacă și cum ar putea să se implice. Aceasta a presupus evaluarea obiectivelor rusești, consilierea Ucrainei cu privire la modul de reacție şi examinarea implicaţiilor pentru orice conflict care ar putea apărea între Rusia și un membru al NATO în viitor.

\section{Concluzii}

După anexarea ilegală, Crimeea a devenit un avanpost apetisant pentru politica Kremlinului, din această regiune, Rusia putând să-ți proiecteze nestingherită influența în apele calde ale Mării Negre, Mediteranei și în Orientul Mijlociu. Cu acces maritim în aceste zone, Rusia întreține și amplifică tensiunile din Libia și în Siria, demonstrându-și abilitatea de a strica toate proiectele occidentale legate de stabilitate, siguranță energetică sau economică. Toată această strategie, care demonstrează și o incapacitate a Rusiei de a construi ceva sustenabil global, este menită să impună Rusia ca un actor global care contează în stabilirea direcției mizelor geopolitice dintre Occident şi actorii din Orientul Mijlociu și statele MENA.

După invadarea peninsulei Crimeea și amplificarea conflictelor din sud-estul Ucrainei, a devenit evident că politica Rusiei este axată pe prezervarea sferei de influenţă și a controlului strategic asupra deciziilor și direcțiilor politice luate de statele desprinse din fostul bloc sovietic. Kremlinul a adoptat mai multe strategii pentru păstrarea controlului asupra fostelor regiuni, fie prin atragerea statelor în alianțele și uniunile euroasiatice (de exemplu, Belarus), fie prin facilitarea apariției unor conflicte înghețate în anumite regiuni devenite separatiste, decuplate de la statul de origine (de exemplu, Abhazia, Osetia de Sud, Transnistria, Nagorno-Karabah), fie, în cazuri considerate de extremă necesitate, prin enclavizarea și anexarea teritorială a unor regiuni desprinse din statele de origine (de exemplu, Crimeea). Toate aceste strategii au un catalizator comun: minoritatea rusă. În statele în care nu există o minoritate rusă semnificativă, dar care prezintă interes geostrategic pentru Federația Rusă, aceasta adoptă alte strategii neconvenționale sau hibride, aflate, de regulă, sub limita detectabilității, apelând la instrumentar hibrid, de genul propagandei negre, politicii energetice, diplomatice, cibernetice, informaționale, sau coruperii liderilor.

Înfruntarea dintre Rusia și Occident, care a conduslaconflictulruso-ucrainean, aridicatîntrebări importante cu privire la credibilitatea NATO, ca garantal securitățiieuropene. Desfăşurareacusucces a instrumentarului hibrid în Ucraina a demonstrat complexitatea războiului de nouă generație, dus de Rusia. În locul angajării unei invazii militare clasice în Ucraina, care ar fi atras sancțiuni fără precedent pentru Federația Rusă, aceasta a adoptat o strategie insidioasă și subversivă, care a constat într-un mix de instrumente şi tactici, îmbinate ingenios, care au facilitat atingerea scopului politic al Kremlinului. Astfel, pentru anexarea Crimeii, Rusia a desfăşurat forțe speciale militare și paramilitare, fără însemne, campanii de informare susținută, propagandă media, agresiuni cibernetice și electronice, constrângeri economice, energetice sau politice. Problema geopolitică pe care Occidentul va trebui să o abordeze este legată de cum ar putea reacționa NATO la evoluții similare, în special dacă statul agresat ar putea fi un stat membru al Alianței. Abilitatea Rusiei de a implementa tactici hibride și subversive face redundantă nevoia de a uza de mijloace convenționale de război.

Dilema Occidentului este dacă agresiunile hibride ale Federaţiei Ruse împotriva statelor membre ale NATO pot fi anticipate și pot atrage un răspuns din partea Alianței, prin eliminarea pragului de acțiune împotriva sa. Prin urmare, este important să se studieze strategia Rusiei, de utilizare a tacticii hibride, având, ca studii de caz, agresiunile din Georgia sau Ucraina. Înțelegerea modului în care diferite instrumente pot fi folosite de Federaţia Rusă pentru a influența statele din proximitatea sa și, în special, a modului în care combinarea acestora conduce la o satisfacere eficientă a scopurilor este utilă pentru a evalua și a aborda riscurile și vulnerabilitățilesistemice ale statelor aflate în zonele disputate de Rusia și de Occident, din ultimii ani. Este evident că acest aspect nu este relevant numai pentru statele aflate la frontierele Federaţiei Ruse, globalizarea și competiția acerbă pentru resurse și sfere de influență reverberându-se și asupra altor state aflate în diferite alianțe, organizații sau uniuni economice și militare cu statele afectate. Consider că, deși efectele, asociate cu tacticile hibride 
desfăşurate de Rusia, sunt resimţite în mod natural mult mai acut în statele prooccidentale, dar care nu fac parte din UE sau NATO, precum Ucraina, Georgia, Moldova, Azerbaidjan, utilizarea unor tactici similare sau a unor elemente ale acestora ar putea fi extinse și împotriva actualilor membri ai NATO sau ai UE.

Pentru a putea înțelege efectele războiului ruso-ucrainean asupra Occidentului, precum și pentru a putea anticipa și a contracara o posibilă evoluție viitoare a unor fenomene similare, în state cu risc geopolitic, precum Moldova, dar chiar și în state membre ale NATO, precum țările baltice, România sau Bulgaria, merită să acordăm atenție consecințelor geopolitice ale pierderii Crimeii și a provinciilor de sud-est de către Ucraina. Pentru Federația Rusă, peninsula Crimeea este o bază convenabilă nu doar pentru Marea Neagră, ci și pentru lansarea unor operațiuni militare din Marea Mediterană și Orientul Mijlociu. De altfel, potenţialul economic al Orientului Mijlociu, și competiţia pentru resurse, care a provocat o fricțiune între interesele marilor puteri mondiale, precum Statele Unite, China și Rusia, a transformat Orientul Mijlociu într-una dintre cele mai fierbinți regiuni geostrategice de pe pământ.

Preluarea strategică a peninsulei de către Federația Rusă a condus, printre altele, la o diminuare a capacității militare ucrainene în Marea Neagră, Rusia preluând controlul rutelor comerciale maritime până la Bosfor. Accesul în Transnistria, cu Crimeea subordonată ar permite Rusiei să devină mai puternică în bazinul Mării Negre, în cele din urmă să readucă Turcia din sfera de influență americană și să creeze condițiile pentru rezolvarea problemei surselor alternative și a rutelor de aprovizionare către Europa prin consolidarea poziției în Regiunea Caspică, în viitor.

Anexarea Crimeii a schimbat automat polii de putere din apele teritoriale și din apele care aparțin zonei economice exclusive a Rusiei, ceea ce, în Marea Azov, înseamnă blocada porturilor ucrainene de către aceasta. Anexarea a condus la restricționarea accesului Ucrainei la rute comerciale importante, la porturile din Crimeea, accesul la resursele de petrol și gaze din platoul continental al Mării Negre aflate sub autoritatea trainerilor, controlați de Rusia. Exploatarea acestor zăcăminte de către Ucraina ar fi garantat independența energetică pe o mare perioadă de timp, lucru ce ar fi diminuat capacitatea Rusiei de a mai controla politica ucraineană. Din punct de vedere militar, preluarea Crimeii de către Rusia a permis Kremlinului să mărească potențialul militar rus în această zonă, aflată la frontiera cu Uniunea Europeană și NATO, fapt ce creează o presiune militară asupra Ucrainei, Orientului Mijlociu și Europei de Est.

Privităgeostrategic, prezența RusieiînCrimeea, controlul Transnistriei, alimentarea sentimentelor separatiste în estul Ucrainei și consolidarea alianței militare cu Belarus enclavizează Ucraina, condamnând-o la o schimbare forțată a direcției politice. Problema fundamentală a Ucrainei este că nu aparține niciunui bloc militar, această circumstanță nefavorabilă determinând ca, în cazul unei amenințări, să nu poată conta decât pe forțele proprii. Linia roșie, reprezentată de Crimeea Transnistria - Belarus - Kaliningrad, întărește poziția Federației Ruse faţă de NATO, permițând Rusiei să lanseze o ofensivă militară împotriva statelor membre ale Alianței, din mai multe direcții, în acelaşi timp.

Succesul anexării Crimeii a adus o victorie propagandistică susținătorilor occidentali care simpatizează cu politica Rusiei. Înțeleasă ca lumen ex oriente, aceasta este percepută ca apărător al valorilor creștine tradiționale, al familiei și al căsătoriei sănătoase moral dintre un bărbat și o femeie, în fața viziunilor moderniste ale omului, promovate de instituțiile Uniunii Europene.

\section{NOTE:}

1 Wojciech Łysek, "Crimeea in great powers foreign policy: bordeland-conflict-destabilization", Polskie Towarzystwo Geopolityczne, 11/2015, pp. 37-53, https://www. ceeol.com/search/viewpdf?id=497802, accesat la 21.05.2021.

2 Stepan Rudnicki (1877-1937), membru al Academiei de Științe din Ucraina, istoric, geograf și filolog german.

3 1568-1570, 1676-1681,1686-1700, 1710-1711, 1735$1739,1768-1774,1787-1792,1806-1812,1828-1829,1853-$ $1856,1877-1878,1914-1918$.

4 Michał Siudak, "Geopolityczne Wizje Krymu I Ukrainy", Przegląd Geopolityczny 18, p. 88, https://www. ceeol.com/search/article-detail?id=494566, accesat la 05.04.2021.

5 Halford Mackinder (1861-1947).

6https://www.britannica.com/biography/Halford-Macki nder, accesat la 05.04.2021.

7 L. Diaconescu, „Insula Lumii - Mutarea Centrului Strategic Mondial de la Heartland la Oceanul Indian”, Revista Română de Geografie Politică, 22 (1), 2020, p. 2.

8 Sir Halford J. Mackinder, Democratic Ideals And Reality - A Study in the Politics of Reconstruction, NDU 
Press Defense Classic Edition, 1942, p. XVIII, https://www. files.ethz.ch/isn/139619/1942_democratic_ideals_reality.pdf, accesat la 05.04.2021.

9 https://www.britannica.com/place/heartland, accesat la 05.04.2021.

10 Zbigniew K. Brzezinski, 1928 (reed. 1997), The grand chessboard: American primacy and its geostrategic imperatives / Basic Books -1st ed., p. 46, https:/www.cia. gov/library/abbottabad-compound/36/36669B7894E857AC 4F3445EA646BFFE1_Zbigniew_Brzezinski_-_The_Grand_ ChessBoard.doc.pdf, accesat la 05.04.2021.

$11 \mathrm{https}: / /$ encyclopedia.1914-1918-online.net/article/ concept_of_mitteleuropa, accesat la 05.04.2021.

12 Filosof rus, fondatorul curentului numit neoeurasianism, politolog, sociolog, profesor la Universitatea Lomonosov din Moscova, lider al Mișcării Internaționale Eurasiatice.

$13 \mathrm{http} / /$ www.youtube.com/watch?v=1PPuRlC9fok, http://www.youtube.com/watch?v=FBrQDCpTtFs, http:// www.toutube.com $/$ watch $/ \mathrm{v}=0 \mathrm{IW} 6 \mathrm{v} \_$wfc, accesate la 06.04.2021.

14 Aleksandr Dughin, Teoria lumii multipolare, Universitatea Populară, Chișinău, 2014, p. 191.

15 Oleg Kondratenko, Ukraine as a Geopolitical Priority of the Russian Federation, Universitatea Națională de Aviație, Kiev, Ucraina, 16/2016, pp. 101-116, https://www.ceeol.com/ search/article-detail?id=623548, accesat la 21.05.2021.

16 Iulian Chifu, Oazu Nantoi, Război informațional. Tipizarea modelului agresiunii, Editura Institutului de Științe Politice și Relații Internaționale I.C. Brătianu, București, 2016, pp. 5-7.

17 Mihai-Cristian Stancu, „Războiul informațional. Studiu de caz: Rolul "Rusia Today" pentru acoperirea misiunii executate de către Federația Rusă în estul Ucrainei, în perioada mai 2014-februarie 2015”, Buletinul Universităţii Naționale de Apărare ,, Carol I” Nr. 4/2019, p. 50.

18 https:/globalnews.ca/news/4260938/russia-strategymaskirovka-military-politics-putin/, accesat la 21.05.2021.

$19 \mathrm{https} / / /$ warisboring.com/maskirovka-is-russiansecret-war/, accesat la 21.05.2021.

20 https://www.digi24.ro/stiri/externe/rusia/vladimirputin-ameninta-din-nou-europa-cu-arma-energetica-existariscul-ca-tranzitul-gazului-prin-ucraina-sa-se-intrerupa1217137, accesat la 08.04.2021.

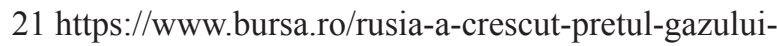
pentru-ucraina-la-485-dolari-pe-1000-metri-cubi-60404323, accesat la 08.04.2021.

22 https://www.economica.net/rusia-ameninta-din-nouucraina-cu-sistarea-furnizarii-gazelor_93764.html, accesat la 08.04.2021.

$23 \mathrm{https} / / /$ www.economica.net/ucraina-trebuie-sacumpere-carbune-de-la-rusia-pentru-a-trece-cu-bine-iarnaministrul-energiei_91326.html, accesat la 08.04.2021.

$24 \mathrm{https}$ ://worldview.stratfor.com/article/energy-instrum ents-hybrid-warfare, accesat la 08.04.2021.

25 Rapoartele recente despre intenția companiei italiene Eni de a fora puțuri de explorare a gazelor de şist din Ucraina au fost însoțite de o explozie de publicaţii critice privind problemele de mediu, care compară producția de gaze de șist cu dezastrul de la Cernobîl. Anunțarea aprovizionării cu combustibil, pentru centralele nucleare ucrainene, de către American Westinghouse Electric Company a stârnit, de asemenea, comentarii critice în mediul experților și promisiunea unui ,al doilea Cernobîl”.

\section{BIBLIOGRAFIE}

Brzezinski Zbigniew K, The grand chessboard: American primacy and its geostrategic imperatives (reed. 1997) Basic Books, A Member of the Perseus Books Group, 1st ed., 1928.

ChifuIulian, OazuNantoi, Război informațional. Tipizarea modelului agresiunii, Editura Institutului de Științe Politice și Relații Internaționale I.C. Brătianu, București, 2016.

Diaconescu L., „Insula Lumii - Mutarea Centrului Strategic Mondial de la Heartland la Oceanul Indian", Revista Română de Geografie Politică, 22 (1), 2020.

Dughin Aleksandr, Teoria lumii multipolare, Universitatea Populară, Chișinău, 2014.

Kaplan Robert, Răzbunarea Geografiei, Editura Litera, București, 2019.

Kondratenko Oleg, Ukraine as a Geopolitical Priority of the Russian Federation, Universitatea Naţională de Aviaţie, Kiev, Ucraina, 16/2016.

Łysek Wojciech, "Crimea in great powers foreign policy: bordeland-conflict-destabilization", Polskie Towarzystwo Geopolityczne, 11/2015.

Mackinder J. Halford, Democratic Ideals And Reality - A Study in the Politics of Reconstruction, NDU Press Defense Classic Edition, 1942.

Maior George, Sergei Konoplyov, Cunoastere strategica in zona extinsa a Marii Negre, Editura RAO, București, 2011.

Siudak Michał, "Geopolityczne Wizje Krymu I Ukrainy", Przeglad Geopolityczny 18.

StancuMihai-Cristian, ,Războiul informațional. Studiu de caz: Rolul «Rusia Today» pentru acoperirea misiunii executate de către Federația Rusă în estul Ucrainei, în perioada mai 2014februarie 2015", Buletinul Universității Naționale de Apărare ,C Carol I” Nr. 4/2019.

https://www.britannica.com/biography/Hal ford-Mackinder

https://encyclopedia.1914-1918-online.net/

article/concept_of_mitteleuropa

http://www.youtube.com/

watch?v=1PPuRlC9fok

http://www.youtube.com/

watch? $v=$ FBrQDCpTtFs 
http://www.toutube.com/watch/v=0IW6v_0wfc https://globalnews.ca/news/4260938/russiastrategy-maskirovka-military-politics-putin/

https://warisboring.com/maskirovka-is-russ ian-secret-war/

https://www.digi24.ro/stiri/externe/rusia/vlad imir-putin-ameninta-din-nou-europa-cu-armaenergetica-exista-riscul-ca-tranzitul-gazului-prinucraina-sa-se-intrerupa-1217137 https://www.bursa.ro/rusia-a-crescut-pretulgazului-pentru-ucraina-la-485-dolari-pe-1000metri-cubi-60404323

https://www.economica.net/rusia-amenintadin-nou-ucraina-cu-sistarea-furnizarii-gazelor _93764.html

https://worldview.stratfor.com/article/energyinstruments-hybrid-warfare 